\title{
Cellular processes of v-Src transformation revealed by gene profiling of primary cells - Implications for human cancer
}

\author{
Bart M Maślikowski', Benjamin D Néel², Ying Wu', Lizhen Wang ${ }^{1}$, Natalie A Rodrigues³, Germain Gillet², \\ Pierre-André Bédard ${ }^{1 *}$
}

\begin{abstract}
Background: Cell transformation by the Src tyrosine kinase is characterized by extensive changes in gene expression. In this study, we took advantage of several strains of the Rous sarcoma virus (RSV) to characterize the patterns of $\mathrm{v}$-Src-dependent gene expression in two different primary cell types, namely chicken embryo fibroblasts (CEF) and chicken neuroretinal (CNR) cells. We identified a common set of $\mathrm{v}$-Src regulated genes and assessed if their expression is associated with disease-free survival using several independent human tumor data sets.

Methods: CEF and CNR cells were infected with transforming, non-transforming, and temperature sensitive mutants of RSV to identify the patterns of gene expression in response to v-Src-transformation. Microarray analysis was used to measure changes in gene expression and to define a common set of $v$-Src regulated genes (CSR genes) in CEF and CNR cells. A clustering enrichment regime using the CSR genes and two independent breast tumor data-sets was used to identify a 42-gene aggressive tumor gene signature. The aggressive gene signature was tested for its prognostic value by conducting survival analyses on six additional tumor data sets.
\end{abstract}

Results: The analysis of CEF and CNR cells revealed that cell transformation by v-Src alters the expression of 6\% of the protein coding genes of the genome. A common set of $175 \mathrm{v}$-Src regulated genes (CSR genes) was regulated in both CEF and CNR cells. Within the CSR gene set, a group of $42 \mathrm{v}$-Src inducible genes was associated with reduced disease- and metastasis-free survival in several independent patient cohorts with breast or lung cancer. Gene classes represented within this group include DNA replication, cell cycle, the DNA damage and stress responses, and blood vessel morphogenesis.

Conclusion: By studying the v-Src-dependent changes in gene expression in two types of primary cells, we identified a set of 42 inducible genes associated with poor prognosis in breast and lung cancer. The identification of these genes provides a set of biomarkers of aggressive tumor behavior and a framework for the study of cancer cells characterized by elevated Src kinase activity.

\section{Background}

The v-Src kinase, the product of the Rous sarcoma virus (RSV), has provided a paradigm for the study of signaling pathways and mechanisms of cell transformation by receptor and non-receptor type tyrosine kinases. Its cellular counterpart, c-Src, is a member of a small family of kinases sharing a similar domain organization, overall structure and regulatory mechanism. Members of the

\footnotetext{
* Correspondence: abedard@mcmaster.ca

'Department of Biology, McMaster University, 1280 Main street West,
} Hamilton, ON, L8S 4K1, Canada
Src family of kinases (SFK) contribute to several aspects of the activity of receptor tyrosine kinases including receptor turn-over, reorganization of the cytoskeleton and the initiation of DNA synthesis [1].

A role for $\mathrm{c}$-Src in the initiation or progression of human cancer has been documented in several studies. Elevated Src kinase activity has been observed in several human cancers and in particular in breast, ovary, lung, bladder, stomach and colon carcinomas [2]. The majority of breast tumors samples $(>70 \%)$ show elevated $\mathrm{Src}$ kinase activity that reflects increased protein levels [3].
C Biomed Central

C 2010 Maślikowski et al; licensee BioMed Central Ltd. This is an Open Access article distributed under the terms of the Creative Commons Attribution License (http://creativecommons.org/licenses/by/2.0), which permits unrestricted use, distribution, and reproduction in any medium, provided the original work is properly cited. 
While c-Src over-expression is not sufficient to induce cell transformation, c-Src likely cooperates with other tyrosine kinases, such as the EGF receptor, frequently over-expressed in the same tumors. An activating mutation resulting in the deletion of the c-Src C-terminal region adjacent to the negative regulatory tyrosine (Y530) has also been identified in a subset of patients with advanced colon carcinomas [4]. This mutation mimics the oncogenic activation of $\mathrm{v}$-Src, whose C-terminus lacks the C-terminal Src kinase (Csk) phosphorylation site.

Signaling pathways controlling cell proliferation or survival, in particular the Ras and PI3K pathways, have been the subject of intense investigation in $\mathrm{v}$-Src transformed cells [5-7]. More recently, elevated Src kinase activity has been linked to several aspects of tumorigenesis including modification of the tumor micro-environment, vasculogenesis, metastasis and the acquisition of chemoresistance $[8,9]$. The mechanisms by which Src controls these properties of tumor cells remain largely unknown. One of the earliest and defining observations of v-Src transformation is the capacity of this oncoprotein to modify the pattern of gene expression. This was revealed by the cloning and characterization of genes aberrantly expressed in $\mathrm{v}$-Src transformed cells, including genes encoding metalloproteinases and chemokines, and the trans-acting factors regulating their expression [10-14]. Investigations based on gene disruption or the use of dominant-negative mutants established the importance of transcription factors such as AP-1, members of the STAT and Ets families, and c-Myc in the proliferation and behavior of $\mathrm{v}$-Src transformed cells [15-22].

Gene profiling studies of transformed cells or tumors characterized by elevated Src kinase activity have documented the changes in gene expression associated with this oncoprotein [23-26]. However, these studies did not assess the transformation-dependence of gene expression [23]. Often they were performed on heterogeneous tumor specimens that limit the sensitivity of the analysis or in immortalized cell lines that may not reveal the full range of Src-dependent changes in gene expression. In this study, we employ a different strategy by comparing the expression profiles of two different primary cell types infected by the Rous sarcoma virus, namely chicken embryo fibroblast (CEF) and chicken neuroretinal cells (CNR). By using temperature sensitive or transformation deficient mutants of $\mathrm{v}$-Src, we define a common set of genes regulated by $\mathrm{v}$-Src. The expression of a group of $42 \mathrm{v}-\mathrm{Src}$ inducible genes of the common set was associated with reduced disease-free survival in independent cohorts of patients with breast carcinomas. High expression of this gene set was also observed in primary tumors of patients with reduced bone or lung metastasis-free survival, suggesting that the common program of $\mathrm{v}$-Src transformed cells is enriched for genes associated with a more aggressive tumor phenotype. The definition of this $\mathrm{v}$-Src gene signature provides a set of biomarkers for the identification of tumors with an aggressive phenotype and the framework for the study of cellular properties conferred by high Src kinase activity in human tumors.

\section{Methods}

\section{Cell culture and RSV strains}

Chicken embryo fibroblasts (CEF) were isolated from day 10 embryos while chicken neuroretinal cells (CNR) were isolated from the retina of 7 day old embryos, as described before [27]. CNR cells do not proliferate in the absence of serum or a transforming $\mathrm{v}$-Src kinase and therefore were infected with the $w t$ Schmidt Ruppin-A strain (SR-A) of RSV or with the temperaturesensitive mutant ts NY72-4 RSV. CEF were infected with the RSV strains $w t$ SR-A, $t s$ NY72-4 and $t d$ NY315 or with RCASBP-A, a derivative of avian sarcoma viruses lacking a viral Src gene. All viruses belong to the A sub-group of ASV. Characterization of the ts NY72-4 and $t d$ NY315 RSV mutants were described before $[28,29]$. CNR and CEF were cultured in high glucose Richter's modified MEM medium (HyClone \#SH30601) supplemented with 5\% cosmic calf serum (HyClone \#SH30087.03), 5\% tryptose phosphate broth, glutamine, penicillin and streptomycin. All studies were performed with actively dividing cells cultured in medium replenished the day before sample preparation to avoid starvation and acidosis of the transformed cells. Populations of $t$ N NY72-4 RSV-infected CNR cells were expanded at the permissive temperature of $37.5^{\circ} \mathrm{C}$ while $\mathrm{CEF}$ were cultured at the non-permissive temperature of $41.5^{\circ} \mathrm{C}$ until transferred to the permissive temperature of $37.5^{\circ} \mathrm{C}$ to induce transformation. For PI3K inhibition, CEF were treated for 8 hours with either a $100 \mathrm{~nm}$ dose of wortmannin (Biomol Research Laboratories, Pennsylvania) or a $15 \mu \mathrm{M}$ dose of LY290042 (Biomol Research Laboratories, Pennsylvania). Animal use was approved by the McMaster University Animal Research Ethics Board (AUP\#05-06-26) and conducted in accordance with the guidelines of the Canadian Council on Animal Care.

\section{RNA isolation and northern blotting analysis}

Total cell RNA was isolated using Trizol reagent (Invitrogen). Ten $\mu$ g of total RNA was loaded per well and separated on a $1.2 \%$ agarose gel containing $3.75 \%$ formaldehyde. RNA was transferred to nylon membrane (Schleicher \& Schuell) by capillary transfer, cross-linked, and probed with randomly primed radiolabeled DNA fragments as described before [30]. Signals detected on northern blots were quantified directly by phosphor-imaging 
using a Storm 820 phosphorimager (Molecular Dynamics) or by scanning autoradiographs on a Umax Astra $1220 \mathrm{U}$ scanner. Images were quantified using ImageJ [31] and adjusted for loading using GAPDH.

\section{Gene profiling analyses}

RNA samples were isolated using Trizol (Invitrogen). RNA quality was assessed by gel electrophoresis and examined with a Bioanalyzer (Agilent). All RNA samples were first analyzed by northern blotting analysis and probed for IL8 and GAPDH expression. RNA samples with a RNA Integrity of less than 9.7 were discarded. Microarray experiments were conducted at the Toronto Centre for Applied Genomics (TCAG) at the Hospital for Sick Children (Toronto, Canada). Biotinylated cRNAs were generated at TCAG and hybridized to Affymetrix Chicken GeneChip arrays using standard Affymetrix protocols (EukGE-WS2v4). GeneChips were scanned using the Affymetrix GeneChip Scanner 3000. Feature intensity was quantified using Command Console software and exported to CEL format.

CEL files were analysed using dChip software version 2007 [32]. Array data were normalized against the median intensity array for each experiment using the invariant set normalization method [33]. Median array intensities for the three experiments were scaled to the same value prior to normalization in order to provide comparable probe intensities for inter-experimental comparison. Expression levels were determined by the model-based expression index method using perfectmatch probes only $[33,34]$. Two-fold changes in gene expression between experimental conditions within each experiment were determined using log-transformed expression values and statistical significance of expression was determined using one-way ANOVA (RCASBP/ NY315/SR-A comparison using RCASBP(A) and NY315 as control groups) or an unpaired two-tailed t-test (NY72-4 CEF and CNR comparisons). Probe-sets whose $\mathrm{p}$-values were greater than 0.05 (pairwise comparisons) or 0.01 (ANOVA) were excluded from further analysis. False discovery rates in all comparisons were estimated to be less than $3 \%$ by permutation (10,000 permutations; [35]). For clustering, redundant genes were removed by identifying probe-sets whose Entrez Gene and/or reference sequence IDs were identical. Probe-sets with the lowest p-values were retained. Gene clustering was performed using unsupervised hierarchal clustering by average Euclidean distance [36]. Venn diagrams were drawn using Vennmaster v. 0.35 [37].

Experimental groups were divided into the following: CEF infected by RCASBP(A), NY315 RSV, or SR-A RSV (experimental group 1); CEF infected by ts NY72-4 RSV and grown either at the permissive or non-permissive temperature (experimental group 2); and CNR cells infected by ts NY72-4 RSV and grown either at the permissive or non-permissive temperature (experimental group 3). A minimum of three biological replicates per experimental condition was used. An additional three RCASBP(A)-infected CEF samples cultured at $37.5^{\circ} \mathrm{C}$ were used to control for temperature effects (normalized within experimental group 1). Temperature-regulated genes (determined using the same criteria as for the experimental groups) were cross-referenced to all differentially expressed genes from the CEF ts NY72-4 and CNR tsNY72-4 experiments. Genes whose change in magnitude expression was greater than or equal to the same genes found to be differentially expressed in the SR-A/RCASBP(A) experiment were considered to be temperature-regulated and not attributable to $\mathrm{v}$-Srcdependent transformation. This includes 13 genes from the CEF ts NY72-4 and 16 genes from the CNR ts NY72-4 experiments respectively (Additional File 1). Arrays in each experimental group were normalized within said experimental group to prevent skewing of data points from tissue-effects as determined by M-A plots for individual arrays. Array data are accessible through the Gene Expression Omnibus http://www.ncbi. nlm.nih.gov/geo/ using the accession number GSE14489.

\section{Gene ontology and pathway analyses}

Gene ontology (GO) analyses were conducted using the DAVID 2.0 bioinformatics resources [38,39] functional annotation tool using an EASE score of 0.05 and a minimum of two genes per term. Pathway analyses were carried out using Pathway Express software available in the Onto-tools package [40]. Probe-sets associated with significantly differentially expressed genes from each experimental group were converted to the orthologous probe sets from the Affymetrix human U133 Plus 2.0 array. Non-redundant orthologous probe-sets and associated fold change differences (linear-scale) were uploaded to Pathway Express for use in pathway analysis. Pathway analysis was conducted using default settings and only pathways whose corrected gamma-p-value was less than or equal to 0.05 were kept.

\section{Tumor data analyses}

Tumor expression data sets were obtained from the Gene Expression Omnibus at the National Center for Biotechnological Information. Breast tumor data from Pawitan et al. [41] and Ivshina et al. [42] were used as training data sets (Figure 5, panels Ai and Aii respectively). Breast tumor data from Minn et al. [43], colon tumor data from the International Genomics Consortium Expression Project for Oncology http://www.intgen.org/, and breast, lung and ovary tumor data from Bild et al. [44] were used as test sets. All clinical data were obtained from the original publications. 
Orthologous probe-sets (Hu95av2, U133, U133 Plus 2.0 Affymetrix arrays) for the CSR gene set were obtained from NetAffyx (Affymetrix).

To ascertain if up-regulated genes in the CSR set could be used as markers of poor prognosis in human cancer, orthologous probe-sets corresponding to the upregulated genes in the CSR set were obtained for the Affymetrix platforms used in the training data sets. Only the up-regulated orthologous CSR probe-sets were used for clustering of the Pawitan and Ivshina training sets. Unsupervised gene and sample clustering (Pearson correlation distance metric [36]) was performed on the two training data in order to identify clusters of tumors with similar gene expression profiles. Each tumor cluster was subjected to survival analysis in order to identify tumor clusters associated with poor survival. Since the objective was to identify up-regulated CSR genes associated with poor prognosis, the genes whose expression was statistically significantly higher in the poor-prognosis tumor set versus the other three sets were chosen as candidates for the aggressive gene signature (t-test, single-tailed, $\mathrm{p}<0.05)$. The common set of 42 genes identified from the two training sets defined the aggressive gene signature.

For the test data, the sets of tumors expressing high levels of the aggressive signature were defined as the upper quartile of tumors from any given test set with the highest average gene-wise mean-centered expression of the aggressive signature set. Survival analyses were carried out using the Kaplan-Meier product limit estimator method [45] and statistical significance was evaluated using the log-rank test.

\section{Immunofluorescence and western blotting}

CEFs were grown to sub-confluence on glass slides, rinsed with PBS twice and fixed in 1\% formaldehyde/ PBS for ten minutes. Cells were washed three times for ten minutes in PBS and incubated with anti-CD44-FITC antibody (Abcam, cat. \# ab24907) for 2 hours at room temperature and washed three times for ten minutes in PBS. Cells were visualized on a Nikon Eclipse TE2000-U inverted microscope. Western blotting was performed as described before [46] using the following antibodies: anti-GSK3- $\beta$ and phospho-S9-GSK3- $\beta$ (Cell Signaling \#9332 and 9336S), anti-heme oxygenase 1 (Stressgen, \#SPA-896), anti-PKB (New England Biolabs \#9272), anti-phospho-PKB (Cell Signaling \#9271), anti-Erk1 (Santa Cruz Biotechnology \#sc-94), and anti-Twist1 (Santa Cruz Biotechnology \#sc-15393). Autoradiographs were scanned on a Umax Astra 1220 U scanner, quantified using Image J and corrected for loading using Erk1 [31].

\section{Preparation and cloning of DNA fragments}

RNA was isolated from $10^{7}$ CEFs using Trizol reagent (Invitrogen) as per manufacturer's directions. One $\mu \mathrm{g}$ of RNA was reverse transcribed (Invitrogen SuperScript RT) and treated with RNAse A (Invitrogen). Double-stranded DNA probes for northern blotting analyses were PCR amplified using Promega GoTaq and the appropriate forward/reverse primers (Table 1). DNA fragments were gel-purified and cloned into pCR2.1-TA (Invitrogen) vector as per manufacturer's directions. All cloned products were verified by sequencing at the MOBIX sequencing facility, McMaster University. CEF4/IL8 and glyceraldehyde-3-phosphate dehydrogenase (GAPDH) probes were generated as described previously [30].

\section{Results \\ Identification of Transformation-Regulated genes in v-Src transformed CEF}

To identify genes regulated in a transformation-dependent manner, we characterized the gene expression profiles of CEF transformed by the wt RSV strain Schmidt Ruppin - group A (SR-A) or infected with the

Table 1 Primer sequences used for the amplification of probe DNA.

\begin{tabular}{|c|c|c|}
\hline Gene & Forward primer & Reverse primer \\
\hline CD44 & TTACTCCGTACTCACATATGCC & CGTCACATGCTCCTGTTCG \\
\hline DKK3 & AAAACCCAGCATACACACTGC & CAGACTTCACACCTGCTTGG \\
\hline HMOX1 & CTGCCCTGGAGAAAGACTTG & AAGCTCTGCCTITGGCTGTA \\
\hline ITGA1 & СТСТTСТСТАСАTTACGACG & ATITCTTCTTCAGTGGC \\
\hline ITGA6 & GTAATGGCAAATGGCTG & GAACGCTGGAAGAACC \\
\hline ITGA8 & TGGAAAGAGGGAAGAGC & AAGAAGATTGGTGGAAGG \\
\hline NOV & ATGAAGTGCTCCTGGGAGG & GACATGGGATCTAATGGCTGG \\
\hline PLCPI & СTCСTCAGAACCACTGCACA & TTCAAGTGTATTTTATTCTCCTGCAT \\
\hline THBS2 & GGGTTATTCGCCACCAAGG & TAGACCTAATCGTCCACCAGC \\
\hline UPP1 & TATGAAGGACAGGGCAGGTT & TICAAACGTCACAGCAAGC \\
\hline VIP & TAGAAAACGAGTTAGCTCCCAGGA & AGAGTTTGCTAGGTGTCCTTCAGA \\
\hline
\end{tabular}


transformation-deficient viruses NY 315 RSV or RCASBP(A). NY315 RSV is a group A virus encoding a catalytically active deletion mutant of the $\mathrm{v}$-Src kinase lacking amino acids 2-14 of the SH4 domain. As a result of this deletion, the $\mathrm{v}$-Src kinase of NY315 RSV is not myristoylated, does not associate with the plasma membrane and is non-transforming [29]. $\operatorname{RCASBP}(\mathrm{A})$ is a group A replication competent virus of the avian sarcoma virus family lacking an oncogene [47]. Total cellular RNA was isolated and analyzed on the Affymetrix chicken GeneChip, an array comprising 37,703 probe sets representing 19,881 UniGene clusters. A total of 3254 probe sets, corresponding to 2904 unique genes were differentially expressed by two fold or greater in cells infected by either NY315 or SR-A RSV (Additional File 2). Within regulated sequences, 2455, 1691 and 730 transcripts were differentially expressed in pair-wise comparisons between SR-A and $\operatorname{RCASBP}(\mathrm{A}), \mathrm{NY} 315$ and $\operatorname{RCASBP}(\mathrm{A})$, and SR-A and NY315 infected CEF, respectively.

Genes regulated in a transformation-dependent manner were identified by one-way ANOVA $(\mathrm{p} \leq 0.01)$ using RCASBP(A) and NY315 as control groups and defined by probe sets with differences in expression greater or equal to two-fold between any two conditions. Unsupervised hierarchal clustering shows that transformation responsive genes cluster to one of two groups, either up-regulated or down-regulated in SR-A RSV transformed CEF but not in the other two conditions (Figure 1). A total of 1095 transcripts corresponding to 418 up-regulated and 535 down-regulated genes were identified in this analysis, defining a set of genes regulated in a transformationdependent fashion. Approximately 15\% of these genes were differentially expressed by five fold or more. We refer to this set of genes as the Transformation-Regulated genes (TR genes) of $\mathrm{v}$-Src transformed CEF (Additional File 3).

Differentially expressed genes were also characterized in CEF infected with the temperature sensitive $(t s)$ mutant NY72-4 RSV. A pair-wise comparison of CEF infected with NY72-4 revealed that 568 transcripts encoded by 477 unique genes (261 up- and 216 down-regulated) were differentially expressed at the permissive versus non-permissive temperatures (Figure 2 and Additional File 4). Cross-referencing of the gene lists provided by the SR-A/NY315/RCASBP(A) and NY72-4 RSV analyses revealed a set of 145 non-redundant genes (or 199 transcripts) corresponding to 84 down- and 61 up-regulated genes associated with cell transformation (Additional File 5).

To control for the effect of temperature change (cold shock), we compared the profile of RCASBP(A) infected $\mathrm{CEF}$ at the permissive temperature of $37.5^{\circ} \mathrm{C}$ and nonpermissive temperature of $41.5^{\circ} \mathrm{C}$ (Additional File 1).

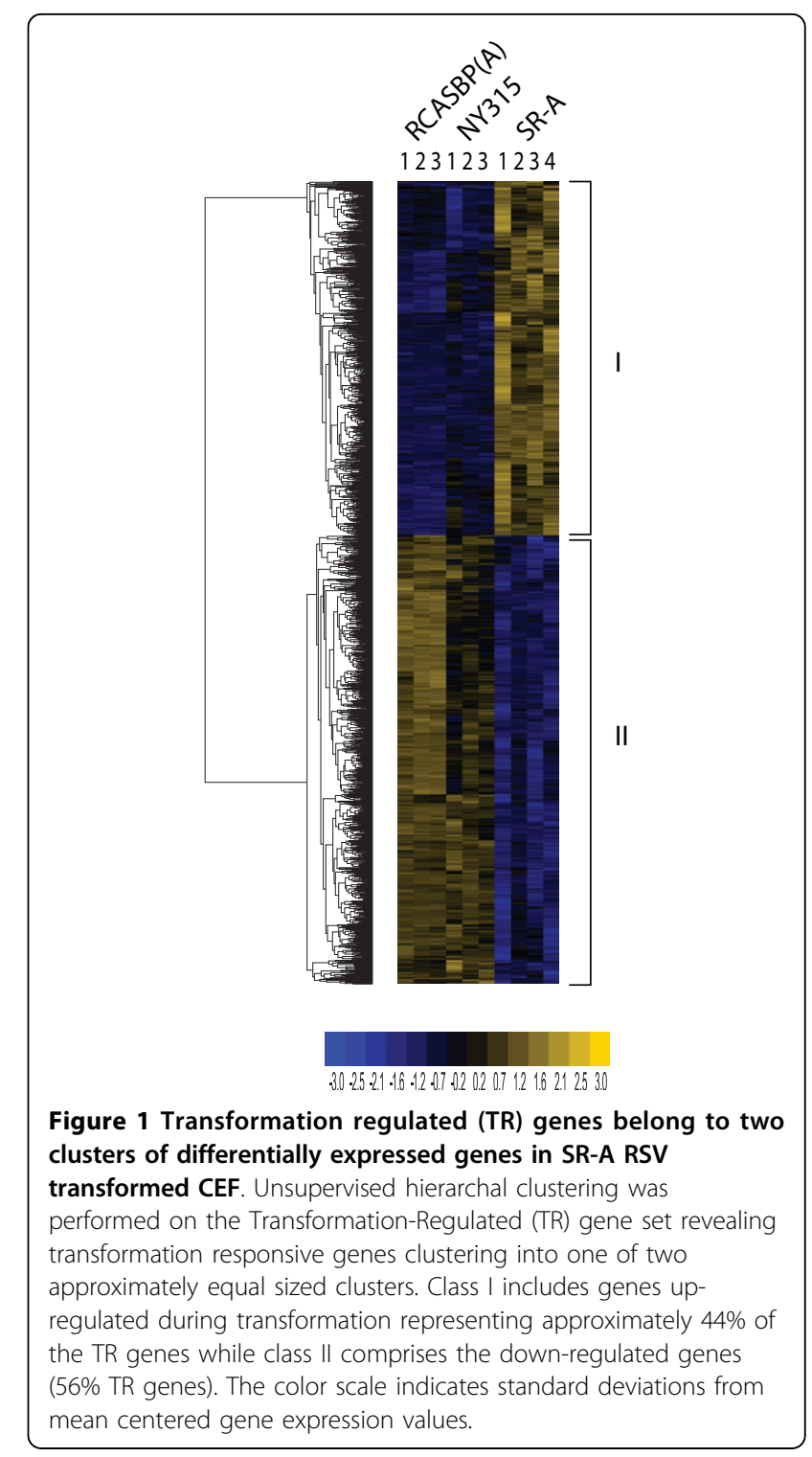

Few genes were differentially expressed by a factor of three or more at the two different temperatures. However, some of the highly $\mathrm{v}$-Src responsive genes (HMOX1, UPP1, Aquaporin 1, for instance) were also regulated by temperature change. Genes affected by temperature and $w t \mathrm{v}$-Src, as determined by the analysis of control and SR-A RSV-transformed CEF at $41.5^{\circ} \mathrm{C}$, indicate a sub-class of genes that are both stress-responsive and v-Src-regulated.

\section{Identification of $\mathrm{v}$-Src regulated genes in chicken neuroretinal (CNR) cells}

In vertebrates, the c-Src kinase is widely expressed and detected in most tissues. In addition, v-Src is capable of transforming a variety of cell types in vitro [48-54]. To compare the biological response of different cell types 


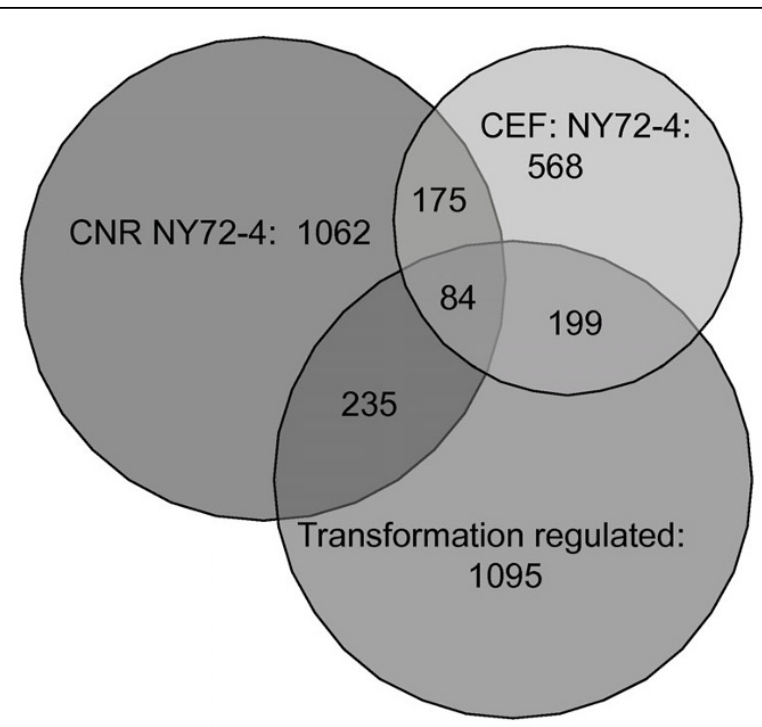

Figure 2 Euler representation of genes differentially expressed between control and v-Src transformed cells. Comparison of gene sets differentially expressed by two-fold between CEF or CNR cells infected with the temperature sensitive mutant NY72-4 RSV, or the set of Transformation-Regulated (TR) genes defined in Additional File 3. Numbers indicate total probe sets.

transformed by v-Src, we characterized the patterns of gene expression of chicken neuroretinal (CNR) cells infected with the temperature-sensitive mutant $t s$ NY724 RSV. Unlike CEF, neuroretinal cells do not proliferate in vitro unless transformed by an oncoprotein such as $\mathrm{v}$-Src and cultured in serum-containing medium [55]. Therefore, $t$ s NY72-4 RSV infected CNR are quiescent at the non-permissive temperature of $41.5^{\circ} \mathrm{C}$ but are actively dividing and transformed at the permissive temperature of $37.5^{\circ} \mathrm{C}$. Gene profiling analyses of CNR cells identified 1062 transcripts, consisting of 485 up- and 577 down-regulated RNA species, with a two-fold or greater difference in gene expression between the two temperatures (Additional File 6). A significant fraction of the v-Src regulated genes identified in $t s$ NY72-4 RSV (31\%) and SR-A/NY315/RCASBP(A) infected CEF (21\%) overlapped with the corresponding set of genes in CNR cells (Figure 2). The total number of transcripts (probe sets) and genes differentially expressed in the three systems of $\mathrm{v}$-Src transformation is provided in Table 2 . Together, the total genes regulated in these three sets represent approximately $6 \%$ of the protein-coding genes in the chicken genome. When all three systems are compared, a group of 84 common genes are identified as v-Src regulated (Figure 2; Additional File 7).

A second group of 91 genes was regulated in ts NY72-4 RSV infected CEF and CNR cells but not in SR-A RSV transformed CEF (Additional File 8). Up-regulated genes in this list encode several important regulators of cell
Table 2 Summary of probe sets found differentially regulated in all three systems of $\mathbf{v}$-Src regulation.

\begin{tabular}{lcccccc}
\hline & \multicolumn{3}{c}{ Total probe-sets } & \multicolumn{3}{c}{ Unique transcripts } \\
\cline { 2 - 7 } Analysis & up & down & total & up & down & Total \\
\hline Transformation regulated & 483 & 612 & 1095 & 418 & 535 & 953 \\
CEF NY72-4 & 319 & 249 & 568 & 261 & 216 & 477 \\
CNR NY72-4 & 485 & 577 & 1062 & 444 & 503 & 947 \\
\hline
\end{tabular}

Number of transcripts differentially expressed in the Transformation-Regulated dataset (RCASBP(A), NY315, SR-A RSV analysis) and the ts NY72-4 RSV infected CEF and CNR cells is shown. Numbers under the total probe-sets heading indicate the total number of Affymetrix probe-sets hybridizing to differentially expressed transcripts, whereas unique transcripts do not include redundant probe-sets whose Entrez Gene and/or reference sequence ID were identical.

proliferation or behavior including ornithine decarboxylase (ODC), osteopontin, hyaluran synthase 2 (HAS2), cyclin A and cyclin E2. In contrast, the cyclin kinase inhibitor $\mathrm{p} 27^{\mathrm{Kip} 1}$ was down-regulated in NY72-4 RSV transformed CEF and CNR cells. Since CNR cells are amplified and cultured at the permissive temperature for extensive periods of time, it is unlikely that the regulation of these genes represents a transient effect of ts $\mathrm{v}$-Src activation. A more likely explanation for this discrepancy is that differences in the structure of the $\mathrm{v}$-Src kinase encoded by NY72-4 and SR-A RSV account for this specificity in gene regulation. It is also likely that the list of genes defined above (Additional File 7) is an underrepresentation of the gene cohort controlled by v-Src in CEF and CNR cells. A more accurate description of this class of genes can be obtained by combining the genes described in Additional File 7 and the genes regulated uniquely in NY72-4 RSV transformed CEF and CNR cells (Additional File 8). This combined list would then consist of a total of 175 genes that we define as the Common set of v-Src Regulated genes or CSR genes.

\section{Validation and characterization of $\mathrm{v}$-Src regulated genes}

The expression of $\mathrm{v}$-Src regulated genes was confirmed by northern blotting analyses. In this study, the expression of genes identified by gene profiling was compared to that of previously characterized markers of Src transformation including IL8/CEF-4, CD44 and Nov [10,14,56-58]. For all up and down-regulated genes selected, little difference was observed between nontransformed CEF infected with the replication competent virus RCASBP(A) and CEF infected with the transformation-deficient virus NY315 RSV (Figure 3A). As reported before, the kinetics of IL8/CEF-4 RNA accumulation was biphasic and characterized by the rapid accumulation of IL8/CEF-4 (within $1 \mathrm{hr}$ ) followed by a temporary reduction of RNA level between 4 and $8 \mathrm{hrs}$ of temperature shift [59]. Other RNA species (VIP, CD 44, integrin- $\alpha-6)$ accumulated more slowly i.e. between 2 and $4 \mathrm{hrs}$ following $t s \mathrm{v}$-Src activation and did not show the transient down-regulation observed for 


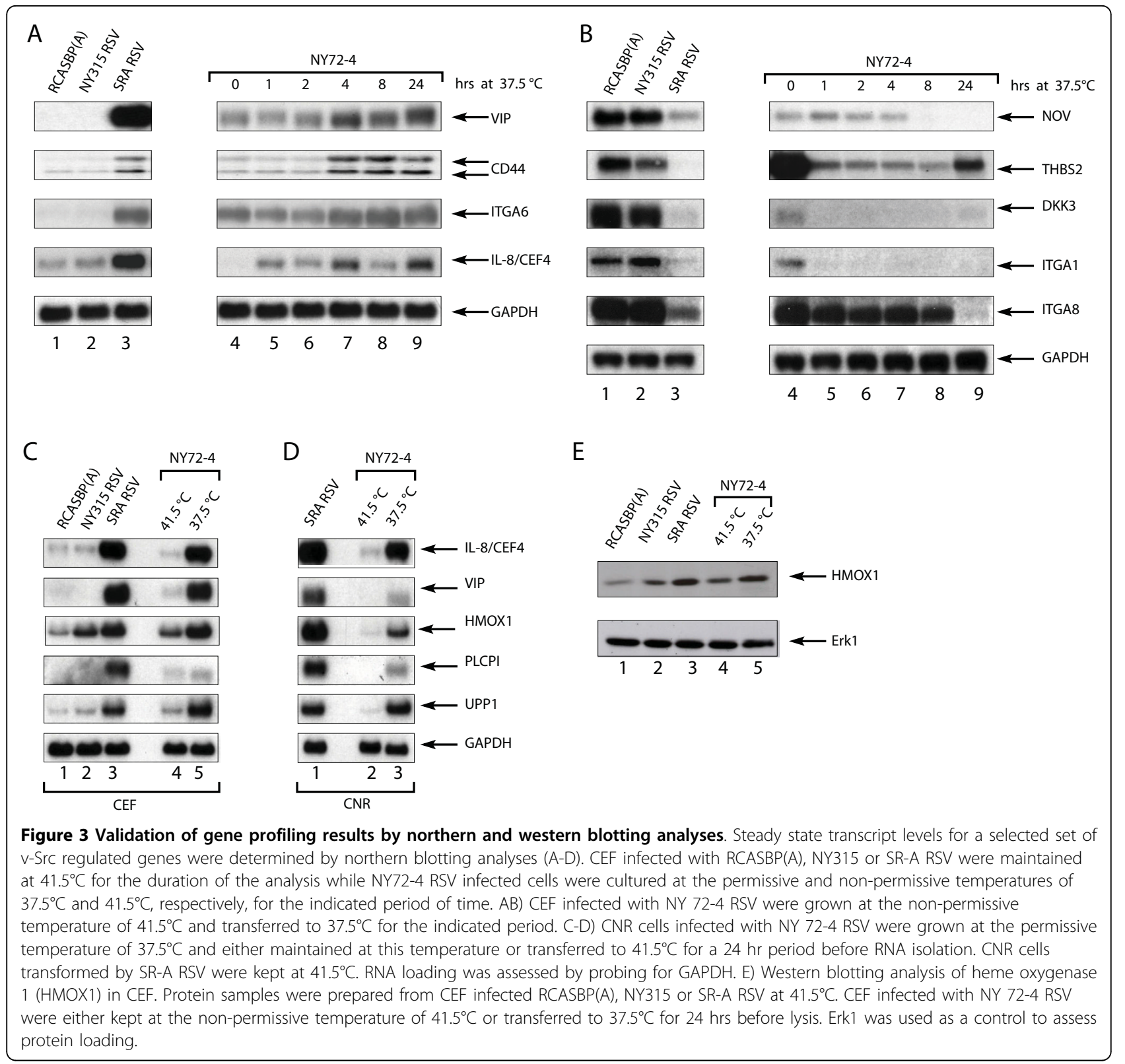

the IL8/CEF-4 mRNA. IL8/CEF-4 and CD44 were both induced in cells treated with cycloheximide indicating that the different kinetics of RNA accumulation do not necessarily reflect a different requirement for de novo protein synthesis (data not shown).

Cell heterogeneity was assessed by looking at the surface expression of CD44 by immunofluorescence (Additional File 9). A strong CD44 signal was observed in SRA RSV transformed CEF but was absent in cells infected with RCASBP(A) and NY315 RSV. All cells expressing the ts mutant of v-Src (NY72-4 RSV) were also positive for CD44 expression at the permissive temperature. Low but detectable signals for CD44 expression were also observed in ts NY72-4 RSV-infected cells at the non- permissive temperature. This may be indicative of a certain degree of leakiness of the ts $\mathrm{v}$-Src kinase, an observation accounting for the lower number of v-Src regulated genes identified in this system.

\section{Characterization of the common set of v-Src regulated genes in CEF and CNR cells}

Differences in the profiles of $\mathrm{v}$-Src regulated genes in CEF and CNR cells reflect in part the proliferative and differentiation state of these cells since CNR cells do not proliferate when non-transformed and are partially committed to differentiation $[55,60]$. However, a common program of gene expression was also evident in the profiles of v-Src transformed CEF and CNR cells. Genes 
such as IL8/CEF4, VIP, HMOX1, PLCPI and UPP1, were all activated in $\mathrm{v}$-Src transformed CEF and CNR cells. HMOX1 also provided an example of a gene with partial activation in CEF infected with NY315 RSV, both at the RNA and protein level (Figure 3C \&3E).

A comparative analysis of $\mathrm{v}$-Src regulated mRNA species examined by northern blotting and microarray profiling was performed for all mRNA species included in Figure 3. This study revealed a strong correlation (Spearman $\rho$ of $0.83, \mathrm{p}<0.0001$ ) between northern and microarray gene expression estimates. A regression coefficient of 0.91 indicates a nearly 1:1 correspondence between northern blotting and microarray gene expression values (Additional File 10, Additional File 11). Collectively the results of the immunofluorescence, northern, and western blotting analyses validated the expression of a sub-set of genes identified in the gene profiling studies and illustrated the existence of a common program of gene expression controlled by $\mathrm{v}$-Src in different cell types.

\section{Signaling pathways and biological processes regulated during v-Src transformation}

Pathways potentially regulated by $\mathrm{v}$-Src-induced changes in gene expression were identified by Pathway Express software [40]. Pathway Express estimates whether genes differentially expressed in a given data set impact a given pathway by incorporating fold-change of gene expression, where those genes are in the hierarchy of a pathway and whether those genes are found to be statistically overrepresented in that pathway. Using this methodology, "ECM-receptor interaction", "focal adhesion" and "phosphatidylinositol signaling" were identified as pathways most significantly altered in all three data sets (corrected $\gamma$ p-value $\leq 0.05$; Table 3 ). TGF $\beta$ signaling was also identified in CEF but not CNR cells. Several pathways were also identified in a single data set and, in particular, in the large cohort of the TransformationRegulated gene set. Thus, "leukocyte transendothelial migration", "complement and coagulation cascades", "cell adhesion molecules", "MAPK" and "Toll-like receptor signaling" pathways were all identified in this data set (Additional File 12).

Pathway Express stresses the regulatory nature of a gene product. This is best illustrated by the genes encoding the pro-survival regulatory and catalytic sub-units of PI3K, which are part of the "focal adhesion", "PI3K" and "leukocyte transendothelial migration" pathways and are hallmarks of several cancer types (ex. "small cell lung cancer"). The up-regulation of both the catalytic and regulatory subunits of PI3K in SR-A RSV transformed CEF implies that the pathway is strongly activated in these cells (Additional File 3). This was confirmed by looking at the phosphorylation status of $\mathrm{PKB} / \mathrm{Akt}$ and GSK3 $\beta$, two downstream targets of the PI3K pathway. High levels of phospho-PKB and phospho-GSK3 $\beta$ were detected in SR-A RSV transformed CEF but not in cells infected with RCASBP(A) or NY315 RSV, even when these cells were actively cycling (Additional File 13). The signal was reduced in cells treated with the specific inhibitor LY294002, indicating that phosphorylation of these proteins was dependent on the PI3K pathway.

Other important regulatory factors are included in the list of Transformation-Regulated genes. An example is provided by Twist1, a bHLH transcription factor promoting metastasis and capable of inducing the epithelial-to-mesenchymal transition (Additional Files 3 \&4; [61]). The up-regulation of Twist1, observed as a 26 $\mathrm{kDa}$ doublet by western blotting, was confirmed in SR-A RSV transformed CEF (Figure 4).

Table 3 Pathway Express output summary.

\begin{tabular}{|c|c|c|c|c|c|c|c|}
\hline \multirow[b]{2}{*}{ Pathway Name } & \multirow[b]{2}{*}{$\begin{array}{c}\text { \# genes in } \\
\text { pathway }\end{array}$} & \multicolumn{3}{|c|}{ \#Input genes in pathway } & \multicolumn{3}{|c|}{ Corrected $\gamma$ p-value } \\
\hline & & TR & $\begin{array}{c}\text { CEF } \\
\text { NY72-4 }\end{array}$ & $\begin{array}{c}\text { CNR } \\
\text { NY72-4 }\end{array}$ & TR & $\begin{array}{c}\text { CEF } \\
\text { NY72-4 }\end{array}$ & $\begin{array}{c}\text { CNR } \\
\text { NY72-4 }\end{array}$ \\
\hline ECM-receptor interaction & 87 & 19 & 10 & 14 & $1.83 \mathrm{E}-11$ & 3.37E-06 & $3.14 \mathrm{E}-07$ \\
\hline Focal adhesion & 195 & 26 & 14 & 19 & $6.87 \mathrm{E}-11$ & $1.44 \mathrm{E}-06$ & 3.47E-06 \\
\hline Phosphatidylinositol signaling system & 77 & 3 & 1 & 3 & 7.71E-10 & 4.80E-11 & $1.71 \mathrm{E}-03$ \\
\hline TGF-beta signaling pathway & 84 & 10 & 7 & N.D. & 2.90E-06 & $2.12 \mathrm{E}-04$ & N.S. \\
\hline Regulation of actin cytoskeleton & 208 & 19 & N.D. & 11 & $1.27 \mathrm{E}-05$ & N.S. & 5.03E-03 \\
\hline Small cell lung cancer & 86 & 12 & 6 & 8 & $2.56 \mathrm{E}-05$ & 9.19E-03 & $1.26 \mathrm{E}-02$ \\
\hline Complement and coagulation cascades & 69 & 4 & 2 & N.D. & $1.31 \mathrm{E}-03$ & $2.15 \mathrm{E}-02$ & N.S. \\
\hline Epithelial cell signaling in Helicobacter pylori infection & 67 & 3 & 1 & N.D. & $2.80 \mathrm{E}-03$ & $1.09 \mathrm{E}-05$ & N.S. \\
\hline Leukocyte transendothelial migration & 116 & 7 & 2 & 7 & $3.19 \mathrm{E}-03$ & $1.73 \mathrm{E}-02$ & 2.75E-02 \\
\hline Type II diabetes mellitus & 44 & 4 & 1 & N.D. & $2.60 \mathrm{E}-02$ & $2.85 \mathrm{E}-02$ & N.S. \\
\hline
\end{tabular}

Common pathways found to be dysregulated in the Transformation-Regulated (TR), CEF NY72-4 and CNR NY72-4 gene sets are shown. The number of genes in the pathway refers to the number of genes in the associated KEGG pathway (Kyoto Encyclopedia of Genes and Genomes, http://www.genome.jp/kegg/; [102]). Input genes refer to the number of differentially expressed genes that were found in that pathway. Corrected $\gamma \mathrm{p}$-value is a measure of significance as calculated by Pathway Express. N.D. and N.S. indicate not determined and not significant (corrected $\gamma$ p-value $>0.05$ ) respectively. 


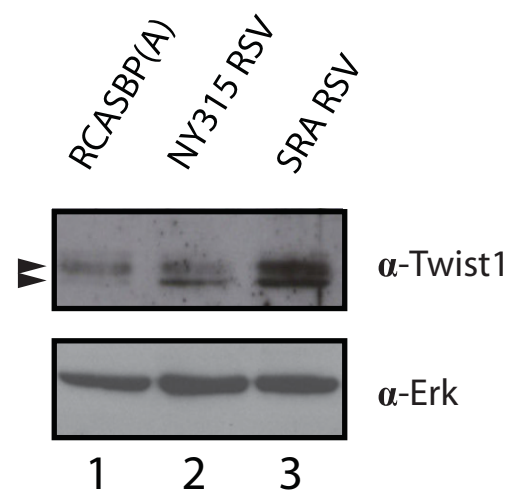

Figure 4 Up-regulation of Twist1 in v-Src-transformed CEF Twist1 protein levels are up-regulated in v-Src transformed CEF. Two Twist 1 immunoreactive protein species of $26 \mathrm{kDa}$ of molecular weight are detected in normal and $\mathrm{v}$-Src transformed CEF.

The Common Set of v-Src Regulated (CSR) genes includes a subset of genes associated with reduced disease-free survival in human cancer

To test whether v-Src-induced changes in gene expression correlate with reduced disease- or metastasis-free survival in human cancers, we undertook a clusteringbased enrichment regime to identify up-regulated genes of the CSR set associated with this phenotype. To this end, two independent breast carcinoma datasets with clinical information were selected and used as training sets. Mammary tumor sets were used because of the abundance of good quality array data obtained on more recent Affymetrix platforms and because a large proportion of breast carcinomas $(>70 \%)$ exhibit high Src activity [3]. It was also reasoned that CSR genes were more likely to be regulated in tumors because their expression is controlled by $\mathrm{v}$-Src in different cell types (i.e. CEF and CNR cells). The aggressive gene signature, defined by clustering analysis, was then tested against additional, independent tumor datasets to assess if it could be used to predict reduced disease-free survival.

Probe-sets corresponding to orthologous genes from the up-regulated CSR set and tumor samples from the two independent breast carcinoma datasets $[41,42]$ were clustered to identify samples containing unique up-regulated gene clusters associated with poor disease-free survival. Survival analyses of these tumor datasets revealed tumor sample clusters associated with higher disease relapse (Figure 5A). Figure 5Ai shows that sample cluster 3 has poorest estimated mean disease-free survival (5.6 years) compared to the other three clusters (7.6, 7.8 , and 6.8 years; clusters 1,2 and 4 respectively; $\mathrm{P}<$ 0.001 ). In Figure $5 \mathrm{~A}$, panel ii, cluster 4 has the poorest estimated mean survival compared to clusters 1,2 and 3 (7.8, 10.1, 10.7 and 8.4 years respectively; $\mathrm{P}<0.01)$ CSR genes that were up-regulated in the low-survival cluster in relation to the other tumor clusters of each tumor data set were cross-referenced to each other to generate an aggressive tumor gene signature (Table 4, see methods). This set contains 42 unique genes overlapping with an $80-87 \%$ concordance with respect to the genes found differentially up-regulated in the two tumor data training sets. This striking overlap represents over $50 \%$ of the 80 up-regulated CSR genes (Additional Files 7 \&8) indicating that the common program of $\mathrm{v}$-Src gene expression is enriched for genes associated with an aggressive tumor phenotype. Functional classification of these genes showed greatest enrichment for gene ontology biological processes (GOBP) such as "Cell Cycle" ("M-phase”, "Mitosis", “Cell Division”), "DNA Metabolic Process" ("Response to DNA damage stimulus"), "Response to Stress", "Cell Proliferation" and "DNA Replication". (Additional File 14)

To assess whether the aggressive tumor gene signature could be used to predict poor disease-free survival, six independent tumor datasets were interrogated to determine if high expression of the 42 genes defining this signature was associated with a poor outcome. By comparing the top $25 \%$ of tumors expressing the highest levels of the aggressive gene signature against the bottom $75 \%$, four data sets out of six showed that patients with tumors characterized by high expression of the 42 gene cohort have reduced disease-free or metastasis-free survival (Figure 5B). Reduced relapse-free survival was seen in the breast and lung carcinoma datasets while reduced lung and bone metastasis-free survival was observed in two other breast tumor datasets.

Analysis of tumors expressing the highest levels of the aggressive signature genes in the breast tumor set from Minn et al., [43] indicated that the patients from whom the tumors were derived had reduced disease-free survival with respect to lung metastasis (mean estimated survival 5.4 years versus 10.1 years, $\mathrm{P}<0.001$; Figure $5 \mathrm{Bi}$ ). Similarly, using bone metastasis data from the same study, the high aggressive signature expressing tumors were associated with reduced metastasis-free survival in patients (mean estimated survival 6.4 years versus 9.3 years, $\mathrm{P}<0.05$; Figure 5Bii). Analysis of a second breast tumor data set [44] also shows that patients whose tumors express high levels of the aggressive signature genes have a reduced disease-free survival (mean estimated survival 71 months versus 106 months, $\mathrm{P}<0.02$; Figure 5Biii). Lung tumor data from the same study indicates a similar trend where patients with tumors expressing high levels of the aggressive signature have reduced disease-free survival (mean estimated survival 29 months versus 54 months, $\mathrm{P}<0.001$, Figure 5Biv). Analysis of ovarian tumor data from the same study however did not yield any statistically significant 


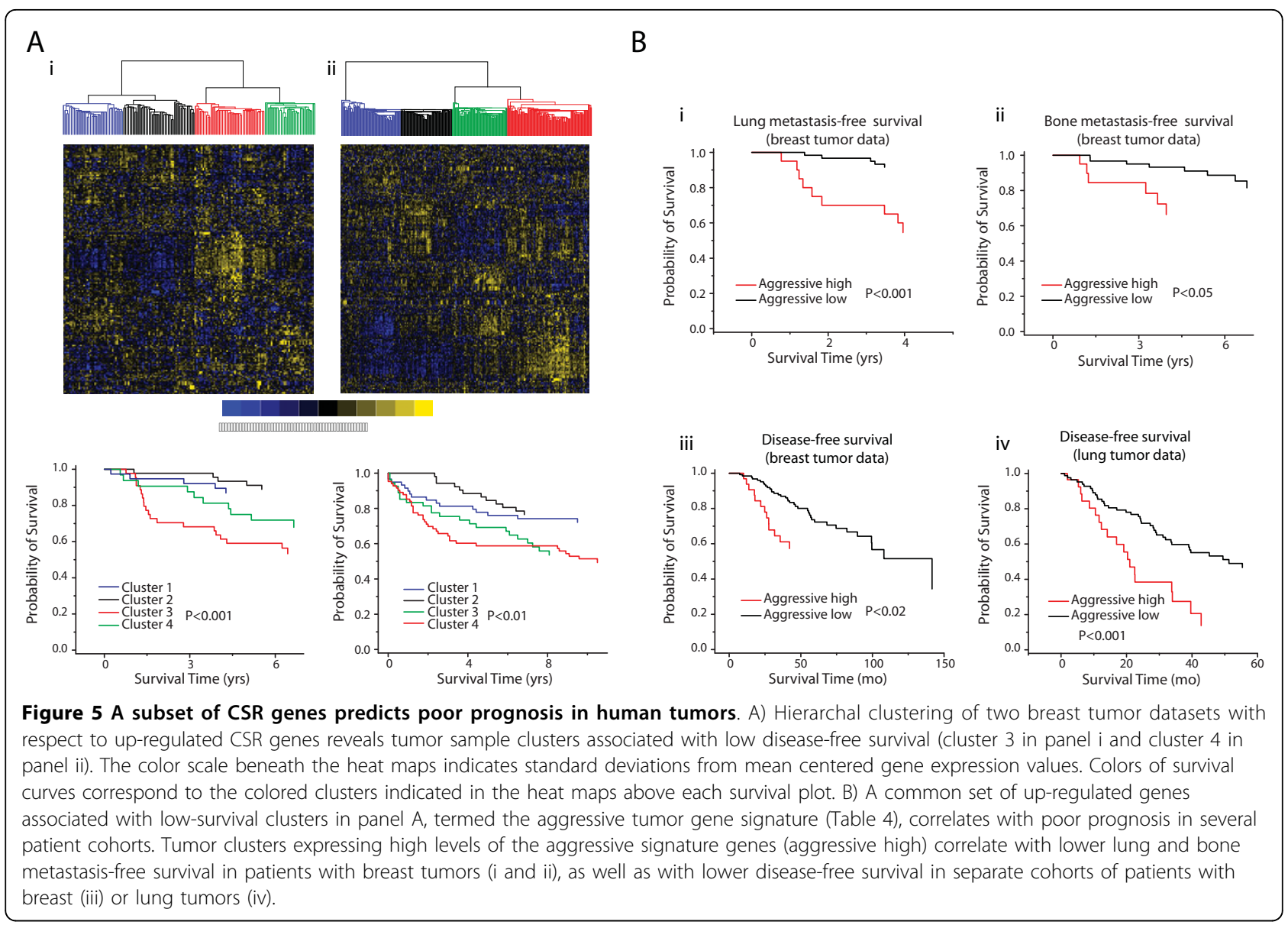

difference (data not shown). Since survival data was not available for the colon carcinoma dataset, we asked whether high expression of the aggressive tumor gene signature could identify patients with distal metastases. Analysis of the relative proportions of metastasis in patients exhibiting high expression of the aggressive signature to those that did not, failed to show any statistically significant difference (data not shown). Taken together, these data show that a subset of the v-Srcregulated CSR genes correlates with poor prognosis in patients with breast tumors, exhibiting some specificity for metastasis to lung and bone.

\section{Discussion}

Definition of a gene signature for v-Src transformation of primary cells

Previous gene profiling studies of $\mathrm{v}$-Src transformed cells have relied principally on the use of immortalized rodent cell lines that may not reflect the full spectrum of biological processes altered during $\mathrm{v}$-Src transformation $[24,25]$. In this study, we used transformation-deficient (NY315 RSV) and temperature sensitive mutants of the Rous sarcoma virus (NY72-4 RSV) to identify gene products regulated in a transformation-dependent manner in primary cells. Further, all experiments were performed in conditions promoting asynchronous cell division and limiting acidosis. A separate study of RSV transformed CEF was reported previously [23]. However, most of the genes identified in our studies (80\%) were not included in the gene set described by these investigators. Moreover, the results of this study differ from ours in some important aspects. First, Masker and co-workers did not assess the transformation-dependence of differentially expressed genes since their analysis was restricted to a pairwise comparison of SR-A RSV transformed CEF and CEF infected with a replication competent virus devoid of any oncogene. Second, several established markers of $\mathrm{v}$-Src transformation such as IL8/CEF-4 and CD44 $[10,14,56]$, were poorly regulated in their experimental conditions and did not pass the significance criteria of the analysis. Third, Masker and co-workers identified some transcription factors such as c-Jun and c-Myc, as being up-regulated by vSrc while we did not. We previously established that early immediate genes such as c-Myc are activated by $\mathrm{v}$-Src in quiescent cells but are not differentially 
Table 4 v-Src aggressive tumor gene signature.

\begin{tabular}{|c|c|}
\hline $\begin{array}{l}\begin{array}{l}\text { Gene } \\
\text { symbol }\end{array} \\
\end{array}$ & Gene name \\
\hline ATAD3A & ATPase family, AAA domain containing $3 \mathrm{~A}$ \\
\hline C13orf3 & chromosome 13 open reading frame 3 \\
\hline CCNA2 & cyclin A2 \\
\hline CCNE2 & cyclin E2 \\
\hline CEP55 & centrosomal protein $55 \mathrm{kDa}$ \\
\hline CSTA & cystatin A (stefin A) \\
\hline E2F8 & E2F transcription factor 8 \\
\hline EAF2 & ELL associated factor 2 \\
\hline EXO1 & exonuclease 1 \\
\hline GAR1 & GAR1 ribonucleoprotein homolog (yeast) \\
\hline HELLS & helicase, lymphoid-specific \\
\hline HMOX1 & heme oxygenase (decycling) 1 \\
\hline HSP90AB1 & $\begin{array}{l}\text { heat shock protein } 90 \mathrm{kDa} \text { alpha (cytosolic), class B } \\
\text { member } 1\end{array}$ \\
\hline IL8 & Interleukin 8 \\
\hline ITGA4 & $\begin{array}{l}\text { integrin, alpha } 4 \text { (antigen CD49D, alpha } 4 \text { subunit of VLA- } \\
4 \text { receptor) }\end{array}$ \\
\hline KIF11 & kinesin family member 11 \\
\hline KIF2A & kinesin heavy chain member $2 \mathrm{~A}$ \\
\hline LBR & lamin B receptor \\
\hline MPP1 & Membrane protein, palmitoylated 1, $55 \mathrm{kDa}$ \\
\hline NASP & nuclear autoantigenic sperm protein (histone-binding) \\
\hline $\mathrm{NOC} 2 \mathrm{~L}$ & nucleolar complex associated 2 homolog (S. cerevisiae) \\
\hline NOP14 & NOP14 nucleolar protein homolog (yeast) \\
\hline NPM3 & nucleophosmin/nucleoplasmin, 3 \\
\hline ODC1 & ornithine decarboxylase 1 \\
\hline PDCD6 & programmed cell death 6 \\
\hline PLAU & plasminogen activator, urokinase \\
\hline RIOK3 & RIO kinase 3 (yeast) \\
\hline RRM1 & ribonucleotide reductase $\mathrm{M} 1$ \\
\hline RRM2 & ribonucleotide reductase $\mathrm{M} 2$ polypeptide \\
\hline SHC4 & $\begin{array}{l}\text { SHC (Src homology } 2 \text { domain containing) family, member } \\
4\end{array}$ \\
\hline SLC2A14 & $\begin{array}{l}\text { solute carrier family } 2 \text { (facilitated glucose transporter), } \\
\text { member } 14\end{array}$ \\
\hline SLC2A3 & $\begin{array}{l}\text { solute carrier family } 2 \text { (facilitated glucose transporter), } \\
\text { member } 3\end{array}$ \\
\hline SLC36A4 & $\begin{array}{l}\text { solute carrier family } 36 \text { (proton/amino acid symporter), } \\
\text { member } 4\end{array}$ \\
\hline SOCS1 & Suppressor of cytokine signaling 1 \\
\hline TRIP13 & thyroid hormone receptor interactor 13 \\
\hline TTC35 & tetratricopeptide repeat domain 35 \\
\hline UHRF1 & ubiquitin-like with PHD and ring finger domains 1 \\
\hline UPP1 & uridine phosphorylase 1 \\
\hline USP1 & ubiquitin specific peptidase 1 \\
\hline USP18 & ubiquitin specific peptidase 18 \\
\hline VRK1 & vaccinia related kinase 1 \\
\hline ZDHHC21 & zinc finger, DHHC-type containing 21 \\
\hline
\end{tabular}

Aggressive gene signature used as a predictor of poor prognosis as determined by hierarchal clustering enrichment regime (see text, Figure 5). expressed when actively dividing cells are compared [14]. Therefore, some of these differences may reflect the experimental conditions of the studies and, in particular, the conditions of cell culture.

A study performed with ts NY72-4 v-Src identified a limited number of $\mathrm{v}$-Src regulated genes in NIH 3T3 fibroblasts [26]. Key transcriptional regulators identified by these authors, such as Hmga2 (high mobility group AT-hook2) and Id4 (inhibitor of DNA binding 4), are also included in the list of $\mathrm{v}$-Src-regulated genes in CNR cells (Additional File 6). In addition, Liu and co-workers described the regulation of important regulators of the cell cycle and angiogenesis by SSeCKS, a metastasis-suppressor gene down-regulated by v-Src [26]. Interestingly, tumor suppressor genes such as DKK3 and gamma FBP $\alpha$, the avian homolog of HIC-1 (hypermethylated in cancer 1 ), were repressed markedly by $\mathrm{v}$-Src in CEF. Thus, the abrupt down-regulation of tumor-suppressor genes may be required for $\mathrm{v}$-Src-dependent cell transformation (Figure 3 and Additional File 3; [26]).

The common set of v-Src regulated genes (CSR genes) is enriched for genes associated with an aggressive tumor phenotype

Since the c-Src kinase is expressed ubiquitously in most vertebrate tissues, we reasoned that genes regulated by $\mathrm{v}$-Src in multiple cell types would better represent targets of this kinase in tumorigenesis. Using CEF and CNR cells, we thus described a common program of gene expression consisting of 175 genes regulated by vSrc in both cell types. This program, referred to as the Common set of v-Src Regulated genes or CSR genes, was then used to interrogate several independent tumor data sets with corresponding clinical information. Beginning with data from two independent cohorts of breast carcinomas as training sets, we performed hierarchal clustering analyses to identify a group of $\mathrm{v}$-Src inducible genes highly expressed in tumors associated with reduced disease-free survival (Table 4). Significantly, the majority $(80-87 \%)$ of the 42 genes included in this group were identified in both independent tumor data sets. Since the CSR gene cohort consists of a total of 80 up-regulated genes, the 42 genes identified in this analysis suggest that CSR genes are highly enriched for genes associated with a more aggressive tumor phenotype. To confirm this finding, we then interrogated several additional tumor data sets including some used previously by other investigators $[43,44]$. This analysis confirmed the expression of the $\mathrm{v}$-Src inducible gene set in primary tumors of patients with reduced disease-free or metastasis-free survival in four of six tumor data sets, including breast and lung carcinomas (Figure 5). In 
contrast, no correlation was observed for ovarian and colon carcinomas suggesting tissue specificity of the $\mathrm{v}$ Src aggressive tumor gene signature. A recent report by Zhang and co-investigators shed some light on the role of Src in bone metastasis of breast cancer cells [9]. Knockdown of c-Src in the highly metastatic human BoM-1833 cell line impaired the proliferation of these cells in the bone micro-environment but had no effect on lymph node metastasis in a mouse model. Moreover, these authors provided evidence that Src enhanced the survival of the metastatic cancer cell line by mediating the activation of $\mathrm{PKB} / \mathrm{Akt}$ in response to CXCR4 activation [9].

Prognostic gene signatures for breast cancer have been described previously by several groups [62-66]. A comparative analysis of the 70-gene, 76-gene and the Gene expression Grade Index (GGI) signatures revealed that they have similar prognostic ability despite limited overlap in gene identity [64]. Recently, $Y u$ et al. showed that a common set of biological processes is enriched among these gene signatures even when defined by different genes. For instance, "Cell Cycle" is enriched in the 70-gene, 76-gene and the 97gene GGI signatures even though cyclin E2 (CCNE2) is the only gene of this pathway common to all three signatures [63,65-67]. Interestingly, CCNE2, the only gene found in more than two signatures [67] was also identified in our aggressive gene signature along with EXO1 and KIF11, found in two other studies $[62,63]$ (Table 4). Functional classification of our 42-gene aggressive signature shows that three of the 16 enriched GOBP terms ("Cell Cycle", "Mitosis" and "DNA replication") are identical to three of the 36 core GOBP terms described by $Y u$ et al. Twelve remaining terms from our aggressive signature map to parent terms of one or more of the 36 core terms while two, "blood vessel morphogenesis" and "cell proliferation", are unique to our gene set (Additional File 14). This similarity in enriched processes shared with other breast cancer signatures reinforces the hypothesis that there is a common aggressive tumor "pathway-signature" [67].

\section{Biological processes defined by the CSR gene signature - DNA damage and the stress response}

Several genes of the DNA damage and stress responses are included in the 42 genes of the aggressive tumor signature. DNA damage resulting from the production of reactive oxygen species (ROS) or DNA replication stress has been observed in cells transformed by several oncogenes [68-72]. However, evidence of DNA damage, as indicated by the levels of $\gamma \mathrm{H} 2 \mathrm{AX}$, is presently lacking in $\mathrm{v}$-Src transformed CEF (our unpublished results). Therefore, the pathways responsible for the production of ROS or replicative stress may be attenuated in these cells. Src-transformed cells are known to be more resistant to conditions of oxidative stress and the induction of genes such as HMOX1 or UPP1 enhance cell survival in conditions of hypoxia or glucose depletion i.e. in conditions promoting the production of ROS [73-77]. Therefore, genes of the aggressive tumor signature may limit the effects of oncogenic stress and provide a survival advantage to the cell.

Several genes identified in this study were also regulated in response to temperature change (cold shock). Since temperature change had a modest effect on the activation of these genes with induction levels of 3-fold or less (Additional File 1), and since all v-Src regulated genes affected by temperature change were also identified in the RCASBP/NY315/SR-A RSV analysis at $41.5^{\circ}$ $\mathrm{C}$, it is unlikely that these genes represent a class of genes regulated uniquely as a result of temperature change. Genes like HMOX1, Aquaporin 1 and the metallothioneins MT2A and 3 are induced in response to a wide variety of stress conditions and are widely regarded as general stress response genes. Since HMOX1, Aquaporin 1 and UPP1 are activated by temperature change and are included in the Common Set of v-Src Regulated (Additional Files $7 \& 8$ ), they may be part of a general and previously unrecognized stressresponse program controlled by $\mathrm{v}$-Src.

\section{Biological processes affected by v-Src transformation: Motility and Invasiveness}

The large cohort of Transformation-Regulated genes (TR genes; Additional File 3) includes several genes that may contribute to a more aggressive tumor phenotype. Src-transformed CEFs are highly motile and characterized by structures mediating cell migration called podosomes $[78,79]$. Like the related invadopodia described in other cancer cells, the podosomes are actin-rich structures closely associated with adhesion molecules and ECM-degrading enzymes such as the matrix metalloproteinases MMP-1, MMP-2 or MMP-9 [80]. In CEF, v-Src transformation stimulated the expression of four critical regulators of actin polymerization and podosome formation, namely N-WASP, cortactin, gelsolin and the p41 subunit of the actin related protein complex 2/3 (Arp 2/3 subunit 1b-p41; Additional File 3[81-84]). Two of these factors (Arp 2/ 3 subunit $1 \mathrm{~b}-\mathrm{p} 41$ and cortactin) were also activated in CNR cells indicating that $\mathrm{v}$-Src controls the expression of these genes in diverse cell types (Additional File 6). The gene encoding the p41 subunit of the Arp $2 / 3$ complex is frequently amplified in pancreatic cancer and is a regulator of the motility and invasion of pancreatic cell lines [85]. In contrast, caldesmon and transgelin were repressed by $\mathrm{v}$-Src in CEF. Transgelin 
is a multi-functional protein with roles independent of podosome formation. In particular, transgelin is a negative regulator of MMP-9 expression and a suspected tumor suppressor $[86,87]$. Independent studies have shown that caldesmon, an actin filament crosslinker, antagonizes the action of the Arp 2/3 complex and is a negative regulator of podosome formation and invasion in transformed cells [88-90]. Therefore, v-Src transformation is characterized by changes in gene expression promoting the dynamic remodeling of the actin cytoskeleton and the assembly of podosomes. It is also significant that $\mathrm{wt} \mathrm{v}$-Src induces the expression of the p110 catalytic subunit, a PI3K isoform required for cell migration in macrophages and breast cancer cells (TR genes; Additional File 3; [91,92]).

\section{Biological processes affected by v-Src transformation:} Epithelial-to-mesenchymal transition and drug resistance Several studies have linked the expression of v-Src and other Src family kinases to resistance of a variety of chemotherapeutic agents including cisplatin, geftinib, paclitaxel, oxaliplatin and tamoxifen [93-97]. Since chemoresistance is often associated with increased cell motility and invasiveness, it has been suggested that v-Src controls these activities by inducing the epithelial-tomesenchymal transition (EMT) in tumor cells [8]. In support of this notion, Sham and co-workers reported recently that the up-regulation of the basic-helix-loophelix factor Twist1 by NF-kB increases chemoresistance of PC3 prostate cancer cells treated with daunorubicin or cisplatin [98]. In a separate report, Cheng et al. identified Twist 1 and its target Akt2/PKB $\beta$ as factors contributing to the metastatic potential of highly invasive breast carcinoma cell lines. In the same study, these investigators showed that Twist1 and Akt2/PKB $\beta$ determine the resistance of these cells to paclitaxel [99]. Twist1 is a potent inducer of the EMT and a member of the Transformation-Regulated gene cohort identified in this study (Figure 4 and Additional File 3). Since forced expression of Twist1 is sufficient to induce the EMT in mammary epithelial cells, the regulation of this factor provides a mechanism by which $\mathrm{v}$-Src may induce the EMT and enhance chemoresistance [61]. Twist1 is not the only marker of the EMT identified in this study since $\mathrm{N}$-cadherin mRNA expression was also up-regulated in SR-A transformed CEF (TR genes; Additional File 3).

\section{Conclusion}

Elevated Src kinase activity has been described in several unrelated human tumors and in cells derived from these tumors [2]. In human cancers, high Src activity correlates with progression to a more malignant phenotype and the increased metastatic potential of tumor cells $[4,100,101]$. In this study, we define a signature of $42 \mathrm{v}$-Src inducible genes whose expression is associated with reduced disease-free survival in breast and lung cancer patients from several independent studies. In one dataset, this 42 gene signature was also associated with reduced bone and lung metastasis-free survival. Several genes of the larger cohort of Transformation-Regulated Genes (TR genes) have also been associated with features of aggressive tumors such as invasiveness and chemoresistance. These genes provide a set of biomarkers and candidate therapeutic targets for the treatment of patients with tumors characterized by more aggressive behavior. The functional characterization of these genes represents a roadmap for the study of tumor cells characterized by elevated Src kinase activity.

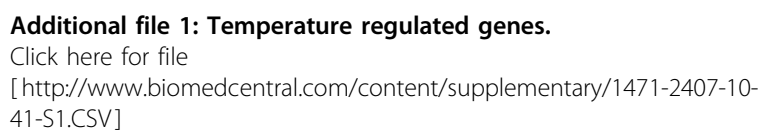

Additional file 2: Pairwise comparisons of CEF infected with RCASBP (A), NY315, or SRA RSV.

Click here for file

[http://www.biomedcentral.com/content/supplementary/1471-2407-1041-S2.CSV]

Additional file 3: Transformation-Regulated genes in CEF.

Click here for file

[http://www.biomedcentral.com/content/supplementary/1471-2407-1041-S3.CSV]

Additional file 4: Genes regulated by ts NY72-4 infected CEF. Click here for file

[http://www.biomedcentral.com/content/supplementary/1471-2407-1041-S4.CSV]

Additional file 5: v-Src regulated genes identified in SR-A and ts NY72-4 RSV transformed CEF.

Click here for file

[http://www.biomedcentral.com/content/supplementary/1471-2407-1041-S5.CSV]

Additional file 6: Genes regulated by ts NY72-4 infected CNR. Click here for file

[http://www.biomedcentral.com/content/supplementary/1471-2407-1041-S6.CSV]

Additional file 7: Genes commonly regulated in all three v-Src transformed cell systems.

Click here for file

[http://www.biomedcentral.com/content/supplementary/1471-2407-1041-S7.DOC ]

Additional file 8: Genes uniquely regulated in NY72-4 RSV transformed CEF and CNR.

Click here for file

[http://www.biomedcentral.com/content/supplementary/1471-2407-1041-S8.DOC ]

Additional file 9: Expression of CD44 in normal and transformed CEF. Surface expression of CD44 was examined by immunofluorescence in CEF infected with RCASBP(A), NY315 or SR-A RSV. NY72-4 infected CEF were either grown at the non-permissive $\left(41.5^{\circ} \mathrm{C}\right)$ or the permissive temperature $\left(37.5^{\circ} \mathrm{C}\right)$ for 24 hours prior to fixing and staining for CD44. Click here for file

[ http://www.biomedcentral.com/content/supplementary/1471-2407-1041-S9.PDF ] 
Additional file 10: Comparison of expression data of v-Src regulated genes as determined by gene profiling and northern blotting analyses. Gene expression by northern blotting analysis (Figure 3) was quantified and analyzed against microarray data to confirm a correlation in gene expression as measured by the two methods. Analysis of correlation of $\log _{2}$-transformed gene expression ratios ( $\log _{2}$ (experimental/baseline)) indicates a strong correlation (Spearman $\rho$ of $0.83 ; p<0.0001$ ) between northern blot and microarray gene expression estimates. This $\rho$ value is higher than typically observed in array validations [103], and consistent with northern blotting as a superior method of gene expression validation [104]. A slope of 0.91 for the regression line indicates a nearly 1:1 ratio between $\log _{2}$ expression ratios of northern and microarray data.

Click here for file

[http://www.biomedcentral.com/content/supplementary/1471-2407-1041-S10.PDF ]

Additional file 11: Comparison of gene expression data quantified from northern blots (Figure3) compared to values obtained from microarray analysis.

Click here for file

[http://www.biomedcentral.com/content/supplementary/1471-2407-1041-S11.DOC ]

Additional file 12: Full Pathway Express output summary. Common pathways found to be dysregulated in the Transformation-Regulated (TR), CEF NY72-4 and CNR NY72-4 gene sets are shown. The number of genes in the pathway refers to the number of genes in the associated KEGG pathway. Input genes refer to the number of differentially expressed genes that were found in that pathway. Corrected $\gamma p$-value is a measure of significance as calculated by Pathway Express. N.D. and N.S. indicate not determined and not significant (corrected $\gamma$ p-value $>0.05$ )

respectively.

Click here for file

[http://www.biomedcentral.com/content/supplementary/1471-2407-1041-S12.DOC

Additional file 13: Activation of the PI3K/PKB-Akt pathway in v-Srctransformed CEF. The activation of PKB-Akt in RCASBP(A), NY315 and SR-A RSV infected CEF was investigated by western blotting analysis. Antibodies for PKB-Akt and the Ser-473 phosphorylated form of PKB-Akt were used to determine the expression and activation of PKB-Akt, respectively. The level of phospho-PKB-Akt was examined in cells treated with 1\% DMSO (D; diluent) or the PI3K inhibitors LY290042 (LY) and wortmannin (W). PKB-Akt was hyper-phosphorylated in v-Src transformed CEF but phospho-PKB-Akt levels decreased upon treatment with the PI3K inhibitors. The activation of PKB-Akt coincided with increased Ser-9 phosphorylation of GSK3- $\beta$.

Click here for file

[http://www.biomedcentral.com/content/supplementary/1471-2407-1041-S13.PDF ]

Additional file 14: GO biological process terms most enriched in the aggressive gene signature.

Click here for file

[http://www.biomedcentral.com/content/supplementary/1471-2407-1041-S14.DOC ]

\section{Acknowledgements}

$\mathrm{BDN}$ is the recipient of scholarships from the Ministère de la Recherche, the Association pour la Recherche sur le Cancer (France) and the European Council of doctorate candidates and young researchers (Eurodoc). This work was made possible by grants from the Association pour la Recherche, the Ligue Nationale contre le Cancer and the Région Rhône Alpes (France) to GG, and the Canadian Institutes of Health Research (MOP\#10272) to PAB.

\section{Author details}

'Department of Biology, McMaster University, 1280 Main street West, Hamilton, ON, L8S 4K1, Canada. ${ }^{2}$ Institut de Biologie et Chimie des Protéines, Lyon, France. ${ }^{3}$ Sunnybrook Health Sciences Centre, 2075 Bayview Avenue, Toronto, ON, M4N 3 M5, Canada.

\section{Authors' contributions}

BMM performed microarray and data analyses, statistics, CEF cell culture, immunofluorescence, immuno-blotting, northern blot probe design and cloning, and contributed to experimental design. BDN derived and cultured the CNR cells and participated in experimental design. YW cultured CEF and performed northern blotting analyses. LW and NAR participated in CEF cell culture, treatment and western blotting analysis. GG participated in experimental design and coordination. PAB conceived and coordinated the study, derived the CEF, and contributed to experimental design. BMM and $\mathrm{PAB}$ wrote the manuscript. All authors read and approved the manuscript.

\section{Competing interests}

The authors declare that they have no competing interests.

Received: 9 October 2009

Accepted: 12 February 2010 Published: 12 February 2010

\section{References}

1. Thomas SM, Brugge JS: Cellular functions regulated by Src family kinases. Annu Rev Cell Dev Biol 1997, 13:513-609.

2. Irby $\mathrm{RB}$, Yeatman TJ: Role of Src expression and activation in human cancer. Oncogene 2000, 19(49):5636-5642.

3. Biscardi JS, Ishizawar RC, Silva CM, Parsons SJ: Tyrosine kinase signalling in breast cancer: epidermal growth factor receptor and c-Src interactions in breast cancer. Breast Cancer Res 2000, 2(3):203-210.

4. Irby RB, Mao W, Coppola D, Kang J, Loubeau JM, Trudeau W, Karl R, Fujita DJ, Jove R, Yeatman TJ: Activating SRC mutation in a subset of advanced human colon cancers [In Process Citation]. Nat Genet 1999, 21(2):187-190.

5. Sugimoto $Y$, Erikson RL: Phosphatidylinositol kinase activities in normal and Rous sarcoma virus-transformed cells. Mol Cell Biol 1985, 5(11):3194-3198.

6. Aftab DT, Kwan J, Martin GS: Ras-independent transformation by v-Src. Proc Natl Acad Sci USA 1997, 94(7):3028-3033.

7. Webb BL, Jimenez E, Martin GS: v-Src generates a p53-independent apoptotic signal. Mol Cell Biol 2000, 20(24):9271-9280.

8. Shah AN, Gallick GE: Src, chemoresistance and epithelial to mesenchymal transition: are they related?. Anticancer Drugs 2007, 18(4):371-375.

9. Zhang XH, Wang Q, Gerald W, Hudis CA, Norton L, Smid M, Foekens JA Massague J: Latent bone metastasis in breast cancer tied to Srcdependent survival signals. Cancer Cell 2009, 16(1):67-78.

10. Sugano S, Stoeckle MY, Hanafusa H: Transformation by Rous sarcoma virus induces a novel gene with homology to a mitogenic platelet protein. Cell 1987, 49(3):321-328.

11. Simmons DL, Levy DB, Yannoni Y, Erikson RL: Identification of a phorbol ester-repressible v-src-inducible gene. Proc Natl Acad Sci USA 1989, 86(4):1178-1182

12. Matrisian LM, Glaichenhaus N, Gesnel MC, Breathnach R: Epidermal growth factor and oncogenes induce transcription of the same cellular mRNA in rat fibroblasts. EMBO J 1985, 4(6):1435-1440.

13. Gillet G, Guerin M, Trembleau A, Brun G: A Bcl-2-related gene is activated in avian cells transformed by the Rous sarcoma virus. EMBO J 1995, 14(7):1372-1381

14. Bedard PA, Alcorta D, Simmons DL, Luk KC, Erikson RL: Constitutive expression of a gene encoding a polypeptide homologous to biologically active human platelet protein in Rous sarcoma virustransformed fibroblasts. Proc Natl Acad Sci USA 1987, 84(19):6715-6719.

15. Wasylyk C, Maira SM, Sobieszczuk P, Wasylyk B: Reversion of Ras transformed cells by Ets transdominant mutants. Oncogene 1994 9(12):3665-3673

16. Turkson J, Bowman T, Garcia R, Caldenhoven E, De Groot RP, Jove R: Stat3 activation by Src induces specific gene regulation and is required for cell transformation. Mol Cell Biol 1998, 18(5):2545-2552.

17. Suzuki T, Murakami M, Onai N, Fukuda E, Hashimoto Y, Sonobe MH, Kameda T, Ichinose M, Miki K, Iba H: Analysis of AP-1 function in cellular transformation pathways. J Virol 1994, 68(6):3527-3535.

18. Lloyd A, Yancheva N, Wasylyk B: Transformation suppressor activity of a Jun transcription factor lacking its activation domain. Nature 1991, 352(6336):635-638. 
19. Johnson R, Spiegelman B, Hanahan D, Wisdom R: Cellular transformation and malignancy induced by ras require c-jun. Mol Cell Biol 1996, 16(8):4504-4511.

20. Granger-Schnarr M, Benusiglio E, Schnarr M, Sassone-Corsi P: Transformation and transactivation suppressor activity of the c-Jun leucine zipper fused to a bacterial repressor. Proc Natl Acad Sci USA 1992, 89(10):4236-4239.

21. Bruder JT, Heidecker G, Rapp UR: Serum-, TPA-, and Ras-induced expression from Ap-1/Ets-driven promoters requires Raf-1 kinase. Genes Dev 1992, 6(4):545-556.

22. Bromberg JF, Horvath CM, Besser D, Lathem WW, Darnell JE Jr: Stat3 activation is required for cellular transformation by v-src. Mol Cell Biol 1998, 18(5):2553-2558.

23. Masker K, Golden A, Gaffney CJ, Mazack V, Schwindinger WF, Zhang W, Wang LH, Carey DJ, Sudol M: Transcriptional profile of Rous Sarcoma Virus transformed chicken embryo fibroblasts reveals new signaling targets of viral-src. Virology 2007, 364(1):10-20.

24. Malek RL, Irby RB, Guo QM, Lee K, Wong S, He M, Tsai J, Frank B, Liu ET, Quackenbush J, et al: Identification of Src transformation fingerprint in human colon cancer. Oncogene 2002, 21(47):7256-7265.

25. Paz K, Socci ND, van Nimwegen E, Viale A, Darnell JE: Transformation fingerprint: induced STAT3-C, v-Src and Ha-Ras cause small initial changes but similar established profiles in mRNA. Oncogene 2004 23(52):8455-8463.

26. Liu Y, Gao L, Gelman IH: SSeCKS/Gravin/AKAP12 attenuates expression of proliferative and angiogenic genes during suppression of $\mathrm{v}$-Src-induced oncogenesis. BMC Cancer 2006, 6:105.

27. Crisanti P, Pessac B, Calothy G: Avian neuroretina cells in oncogene studies. Methods Enzymol 1995, 254:77-97.

28. Garber EA, Mayer BJ, Jove R, Hanafusa $\mathrm{H}$ : Analysis of p60v-src mutants carrying lesions involved in temperature sensitivity. J Virol 1987, 61(2):354-360

29. Cross FR, Garber EA, Pellman D, Hanafusa H: A short sequence for the p $60^{\mathrm{src}} \mathrm{n}$ terminus is required for $\mathrm{p} 60^{\mathrm{src}}$ myristylation and membrane association and for cell transformation. Mol Cell Biol 1984, 4:1834-1842.

30. Gagliardi M, Maynard S, Bojovic B, Bedard PA: The constitutive activation of the CEF-4/9E3 chemokine gene depends on C/EBPbeta in v-src transformed chicken embryo fibroblasts. Oncogene 2001, 20(18):2301-2313.

31. Abramoff MD, Magelhaes PJ, Ram SJ: Image Processing with ImageJ. Biophotonics International 2004, 11(7):36-42.

32. Li CW: DNA-Chip Analyzer (dChip). The analysis of gene expression data: methods and software New York: SpingerParmigiani EG, Irizarry R, Zeger SL 2003.

33. Li C, Hung Wong W: Model-based analysis of oligonucleotide arrays: model validation, design issues and standard error application. Genome Biol 2001, 2(8):RESEARCH0032.

34. Li C, Wong WH: Model-based analysis of oligonucleotide arrays: expression index computation and outlier detection. Proc Natl Acad Sci USA 2001, 98(1):31-36.

35. Tusher VG, Tibshirani R, Chu G: Significance analysis of microarrays applied to the ionizing radiation response. Proc Natl Acad Sci USA 2001, 98(9):5116-5121.

36. Eisen MB, Spellman PT, Brown PO, Botstein D: Cluster analysis and display of genome-wide expression patterns. Proc Natl Acad Sci USA 1998, 95(25):14863-14868.

37. Kestler HA, Muller A, Gress TM, Buchholz M: Generalized Venn diagrams: a new method of visualizing complex genetic set relations. Bioinformatics 2005, 21(8):1592-1595.

38. Dennis G Jr, Sherman BT, Hosack DA, Yang J, Gao W, Lane HC, Lempicki RA: DAVID: Database for Annotation, Visualization, and Integrated Discovery. Genome Biol 2003, 4(5):P3.

39. Hosack DA, Dennis G Jr, Sherman BT, Lane HC, Lempicki RA: Identifying biological themes within lists of genes with EASE. Genome Biol 2003, 4(10):R70.

40. Draghici S, Khatri P, Tarca AL, Amin K, Done A, Voichita C, Georgescu C, Romero R: A systems biology approach for pathway level analysis. Genome Res 2007, 17(10):1537-1545.

41. Pawitan Y, Bjohle J, Amler L, Borg AL, Egyhazi S, Hall P, Han X, Holmberg L, Huang F, Klaar $S$, et al: Gene expression profiling spares early breast cancer patients from adjuvant therapy: derived and validated in two population-based cohorts. Breast Cancer Res 2005, 7(6):R953-964

42. Ivshina AV, George J, Senko O, Mow B, Putti TC, Smeds J, Lindahl T, Pawitan Y, Hall P, Nordgren $H$, et al: Genetic reclassification of histologic grade delineates new clinical subtypes of breast cancer. Cancer Res 2006, 66(21):10292-10301.

43. Minn AJ, Gupta GP, Siegel PM, Bos PD, Shu W, Giri DD, Viale A, Olshen AB, Gerald WL, Massague J: Genes that mediate breast cancer metastasis to lung. Nature 2005, 436(7050):518-524.

44. Bild AH, Yao G, Chang JT, Wang Q, Potti A, Chasse D, Joshi MB, Harpole D, Lancaster JM, Berchuck A, et al: Oncogenic pathway signatures in human cancers as a guide to targeted therapies. Nature 2006, 439(7074):353-357.

45. Kaplan EL, Meier P: Nonparametric estimation from incomplete observations. Journal of the American Statistical Association 1958, 53(282):457-481

46. Papaconstantinou M, Wu Y, Pretorius HN, Singh N, Gianfelice G, Tanguay RM, Campos AR, Bedard PA: Menin is a regulator of the stress response in Drosophila melanogaster. Mol Cell Biol 2005, 25(22):9960-9972.

47. Petropoulos CJ, Hughes SH: Replication-competent retrovirus vectors for the transfer and expression of gene cassettes in avian cells. J Virol 1991 65(7):3728-3737.

48. Boettiger D, Roby K, Brumbaugh J, Biehl J, Holtzer H: Transformation of chicken embryo retinal melanoblasts by a temperature-sensitive mutant of Rous sarcoma virus. Cell 1977, 11(4):881-890.

49. Tato F, Alema S, Dlugosz A, Boettiger D, Holtzer H, Cossu G, Pacifici M: Development of 'revertant' myotubes in cultures of Rous sarcoma virus transformed avian myogenic cells. Differentiation 1983, 24(2):131-139.

50. Pacifici M, Boettiger D, Roby $\mathrm{K}$, Holtzer $\mathrm{H}$ : Transformation of chondroblasts by Rous sarcoma virus and synthesis of the sulfated proteoglycan matrix. Cell 1977, 11(4):891-899.

51. Menko AS, Boettiger D: Inhibition of chicken embryo lens differentiation and lens junction formation in culture by pp60v-src. Mol Cell Biol 1988, 8(4):1414-1420.

52. Crisanti-Combes P, Lorinet AM, Girard A, Pessac B, Wasseff M, Calothy G: Effects of Rous sarcoma virus on the differentiation of chick and quail neuroretina cells in culture. Adv Exp Med Biol 1982, 158:115-122.

53. Yoshimura $M$, Iwasaki $Y$, Kaji A: In vitro differentiation of chicken embryo skin cells transformed by Rous sarcoma virus. J Cell Physiol 1981, 109(3):373-385.

54. Kruger A, Anderson SM: The v-src oncogene blocks the differentiation of a murine myeloid progenitor cell line and induces a tumorigenic phenotype. Oncogene 1991, 6(2):245-256.

55. Gillet G, Michel D, Crisanti P, Guerin M, Herault Y, Pessac B, Calothy G, Brun G, Volovitch M: Serum factors and v-src control two complementary mitogenic pathways in quail neuroretinal cells in culture. Oncogene 1993, 8(3):565-574.

56. Ladeda V, Frankel P, Feig LA, Foster DA, Bal de Kier Joffe E, AguirreGhiso JA: RalA mediates v-Src, v-Ras, and v-Raf regulation of CD44 and fibronectin expression in NIH3T3 fibroblasts. Biochem Biophys Res Commun 2001, 283(4):854-861.

57. Jamal HH, Cano-Gauci DF, Buick RN, Filmus J: Activated ras and src induce CD44 overexpression in rat intestinal epithelial cells. Oncogene 1994, 9(2):417-423.

58. Scholz G, Martinerie C, Perbal B, Hanafusa H: Transcriptional down regulation of the nov proto-oncogene in fibroblasts transformed by p60v-src. Mol Cell Biol 1996, 16(2):481-486.

59. Gonneville L, Martins TJ, Bedard PA: Complex expression pattern of the CEF-4 cytokine in transformed and mitogenically stimulated cells. Oncogene 1991, 6(10):1825-1833.

60. Calothy G, Poirier F, Dambrine G, Mignatti P, Combes P, Pessac B: Expression of viral oncogenes in differentiating chick embryo neuroretinal cells infected with avian tumor viruses. Cold Spring Harb Symp Quant Biol 1980, 44(Pt 2):983-990.

61. Yang J, Mani SA, Donaher JL, Ramaswamy S, Itzykson RA, Come C, Savagner P, Gitelman I, Richardson A, Weinberg RA: Twist, a master regulator of morphogenesis, plays an essential role in tumor metastasis. Cell 2004, 117(7):927-939.

62. Yu K, Lee CH, Tan PH, Hong GS, Wee SB, Wong CY, Tan P: A molecular signature of the Nottingham prognostic index in breast cancer. Cancer Res 2004, 64(9):2962-2968. 
63. Sotiriou C, Wirapati $P$, Loi $S$, Harris A, Fox S, Smeds J, Nordgren H, Farmer $P$, Praz $V$, Haibe-Kains $B$, et al: Gene expression profiling in breast cancer: understanding the molecular basis of histologic grade to improve prognosis. J Natl Cancer Inst 2006, 98(4):262-272.

64. Haibe-Kains B, Desmedt C, Piette F, Buyse M, Cardoso F, Van't Veer L, Piccart M, Bontempi G, Sotiriou C: Comparison of prognostic gene expression signatures for breast cancer. BMC Genomics 2008, 9:394.

65. Wang Y, Klijn JG, Zhang Y, Sieuwerts AM, Look MP, Yang F, Talantov D, Timmermans M, Meijer-van Gelder ME, Yu J, et al: Gene-expression profiles to predict distant metastasis of lymph-node-negative primary breast cancer. Lancet 2005, 365(9460):671-679.

66. van't Veer $L J$, Dai $H$, Vijver van de MJ, He YD, Hart AA, Mao M, Peterse HL, Kooy van der K, Marton MJ, Witteveen AT, et al: Gene expression profiling predicts clinical outcome of breast cancer. Nature 2002, 415(6871):530-536

67. Yu JX, Sieuwerts AM, Zhang Y, Martens JW, Smid M, Klijn JG, Wang Y, Foekens JA: Pathway analysis of gene signatures predicting metastasis of node-negative primary breast cancer. BMC Cancer 2007, 7:182.

68. Vafa O, Wade M, Kern S, Beeche M, Pandita TK, Hampton GM, Wahl GM: cMyc can induce DNA damage, increase reactive oxygen species, and mitigate p53 function: a mechanism for oncogene-induced genetic instability. Mol Cell 2002, 9(5):1031-1044.

69. Lee AC, Fenster BE, Ito H, Takeda K, Bae NS, Hirai T, Yu ZX, Ferrans VJ, Howard $B H$, Finkel $T$ : Ras proteins induce senescence by altering the intracellular levels of reactive oxygen species. J Biol Chem 1999, 274(12):7936-7940

70. Bartkova J, Rezaei N, Liontos M, Karakaidos P, Kletsas D, Issaeva N, Vassiliou LV, Kolettas E, Niforou K, Zoumpourlis VC, et al: Oncogeneinduced senescence is part of the tumorigenesis barrier imposed by DNA damage checkpoints. Nature 2006, 444(7119):633-637.

71. Di Micco R, Fumagalli M, Cicalese A, Piccinin S, Gasparini P, Luise C, Schurra C, Garre M, Nuciforo PG, Bensimon A, et al: Oncogene-induced senescence is a DNA damage response triggered by DNA hyperreplication. Nature 2006, 444(7119):638-642.

72. Mallette FA, Gaumont-Leclerc MF, Ferbeyre G: The DNA damage signaling pathway is a critical mediator of oncogene-induced senescence. Genes Dev 2007, 21(1):43-48.

73. Deichman Gl, Kashkina LM, Mizenina OA, Gorojanskaya EG, Nikiforov MA, Gudkov AV, Dyakova NA, Komelkov AV, Prilutskaya MO, Kushlinsky NE, et al: Mechanisms of unusually high antioxidant activity of RSV-SRtransformed cells and of its suppression by activated p21ras. Int J Cancer 1996, 66(6):747-752.

74. Kocanova S, Buytaert E, Matroule JY, Piette J, Golab J, de Witte P, Agostinis P: Induction of heme-oxygenase 1 requires the p38 MAPK and PI3K pathways and suppresses apoptotic cell death following hypericinmediated photodynamic therapy. Apoptosis 2007, 12(4):731-741.

75. Zuckerbraun BS, Billiar TR: Heme oxygenase-1: a cellular Hercules. Hepatology 2003, 37(4):742-744

76. Choi JW, Yoo BK, Shin CY, Ryu MK, Ryu JH, el Kouni MH, Lee JC, Kim WK, $\mathrm{Ko} \mathrm{KH}$ : Uridine prevents the glucose deprivation-induced death of immunostimulated astrocytes via the action of uridine phosphorylase. Neurosci Res 2006, 56(1):111-118.

77. Choi JW, Shin CY, Choi MS, Yoon SY, Ryu JH, Lee JC, Kim WK, El Kouni MH, $\mathrm{Ko} \mathrm{KH:} \mathrm{Uridine} \mathrm{protects} \mathrm{cortical} \mathrm{neurons} \mathrm{from} \mathrm{glucose} \mathrm{deprivation-}$ induced death: possible role of uridine phosphorylase. J Neurotrauma 2008, 25(6):695-707.

78. Sohara $Y$, Ishiguro N, Machida K, Kurata H, Thant AA, Senga T, Matsuda S, Kimata K, Iwata H, Hamaguchi M: Hyaluronan activates cell motility of vSrc-transformed cells via Ras-mitogen-activated protein kinase and phosphoinositide 3-kinase-Akt in a tumor-specific manner. Mol Biol Cell 2001, 12(6):1859-1868.

79. Platek A, Mettlen M, Camby I, Kiss R, Amyere M, Courtoy PJ: v-Src accelerates spontaneous motility via phosphoinositide 3-kinase, phospholipase $C$ and phospholipase $D$, but abrogates chemotaxis in Rat-1 and MDCK cells. J Cell Sci 2004, 117(Pt 20):4849-4861.

80. Gimona M, Buccione R, Courtneidge SA, Linder S: Assembly and biological role of podosomes and invadopodia. Curr Opin Cell Biol 2008, 20(2):235-241.

81. Tehrani S, Faccio R, Chandrasekar I, Ross FP, Cooper JA: Cortactin has an essential and specific role in osteoclast actin assembly. Mol Biol Cell 2006, 17(7):2882-2895
82. Kempiak SJ, Yamaguchi H, Sarmiento C, Sidani M, Ghosh M, Eddy RJ, Desmarais V, Way M, Condeelis J, Segall JE: A neural Wiskott-Aldrich Syndrome protein-mediated pathway for localized activation of actin polymerization that is regulated by cortactin. J Biol Chem 2005, 280(7):5836-5842.

83. Yamaguchi H, Lorenz M, Kempiak S, Sarmiento C, Coniglio S, Symons M, Segall J, Eddy R, Miki H, Takenawa T, et al: Molecular mechanisms of invadopodium formation: the role of the N-WASP-Arp2/3 complex pathway and cofilin. J Cell Biol 2005, 168(3):441-452.

84. Webb BA, Eves R, Mak AS: Cortactin regulates podosome formation: roles of the protein interaction domains. Exp Cell Res 2006, 312(6):760-769.

85. Laurila E, Savinainen K, Kuuselo R, Karhu R, Kallioniemi A: Characterization of the 7q21-q22 amplicon identifies ARPC1A, a subunit of the Arp2/3 complex, as a regulator of cell migration and invasion in pancreatic cancer. Genes Chromosomes Cancer 2009, 48(4):330-339.

86. Assinder SJ, Stanton JA, Prasad PD: Transgelin: an actin-binding protein and tumour suppressor. Int J Biochem Cell Biol 2009, 41(3):482-486.

87. Nair RR, Solway J, Boyd DD: Expression cloning identifies transgelin (SM22) as a novel repressor of 92-kDa type IV collagenase (MMP-9) expression. J Biol Chem 2006, 281(36):26424-26436.

88. Morita T, Mayanagi T, Sobue K: Reorganization of the actin cytoskeleton via transcriptional regulation of cytoskeletal/focal adhesion genes by myocardin-related transcription factors (MRTFs/MAL/MKLs). Exp Cell Res 2007, 313(16):3432-3445.

89. Yoshio T, Morita T, Kimura Y, Tsujii M, Hayashi N, Sobue K: Caldesmon suppresses cancer cell invasion by regulating podosome/invadopodium formation. FEBS Lett 2007, 581(20):3777-3782.

90. Eves R, Webb BA, Zhou S, Mak AS: Caldesmon is an integral component of podosomes in smooth muscle cells. J Cell Sci 2006, 119(Pt 9):1691-1702.

91. Vanhaesebroeck B, Jones GE, Allen WE, Zicha D, Hooshmand-Rad R, Sawyer C, Wells C, Waterfield MD, Ridley AJ: Distinct PI(3)Ks mediate mitogenic signalling and cell migration in macrophages. Nat Cell Biol 1999, 1(1):69-71.

92. Sawyer C, Sturge J, Bennett DC, O'Hare MJ, Allen WE, Bain J, Jones GE, Vanhaesebroeck B: Regulation of breast cancer cell chemotaxis by the phosphoinositide 3-kinase p110delta. Cancer Res 2003, 63(7):1667-1675.

93. Duxbury MS, Ito H, Zinner MJ, Ashley SW, Whang EE: siRNA directed against c-Src enhances pancreatic adenocarcinoma cell gemcitabine chemosensitivity. J Am Coll Surg 2004, 198(6):953-959.

94. Griffiths GJ, Koh MY, Brunton VG, Cawthorne C, Reeves NA, Greaves M, Tilby MJ, Pearson DG, Ottley CJ, Workman P, et al: Expression of kinasedefective mutants of c-Src in human metastatic colon cancer cells decreases $\mathrm{BCl}-\mathrm{xL}$ and increases oxaliplatin- and Fas-induced apoptosis. J Biol Chem 2004, 279(44):46113-46121.

95. Chen T, Pengetnze Y, Taylor CC: Src inhibition enhances paclitaxel cytotoxicity in ovarian cancer cells by caspase-9-independent activation of caspase-3. Mol Cancer Ther 2005, 4(2):217-224.

96. Hiscox S, Morgan L, Green TP, Barrow D, Gee J, Nicholson Rl: Elevated Src activity promotes cellular invasion and motility in tamoxifen resistant breast cancer cells. Breast Cancer Res Treat 2006, 97(3):263-274.

97. Masumoto N, Nakano S, Fujishima H, Kohno K, Niho Y: v-src induces cisplatin resistance by increasing the repair of cisplatin-DNA interstrand cross-links in human gallbladder adenocarcinoma cells. Int J Cancer 1999, 80(5):731-737.

98. Pham CG, Bubici C, Zazzeroni F, Knabb JR, Papa S, Kuntzen C, Franzoso G: Upregulation of Twist-1 by NF-kappaB blocks cytotoxicity induced by chemotherapeutic drugs. Mol Cell Biol 2007, 27(11):3920-3935.

99. Cheng GZ, Chan J, Wang Q, Zhang W, Sun CD, Wang LH: Twist transcriptionally up-regulates AKT2 in breast cancer cells leading to increased migration, invasion, and resistance to paclitaxel. Cancer Res 2007, 67(5):1979-1987.

100. Talamonti MS, Roh MS, Curley SA, Gallick GE: Increase in activity and level of pp60c-src in progressive stages of human colorectal cancer. J Clin Invest 1993, 91(1):53-60.

101. Termuhlen PM, Curley SA, Talamonti MS, Saboorian MH, Gallick GE: Sitespecific differences in pp60c-src activity in human colorectal metastases. J Surg Res 1993, 54(4):293-298.

102. Kanehisa M, Goto S: KEGG: kyoto encyclopedia of genes and genomes. Nucleic Acids Res 2000, 28(1):27-30. 
103. Morey JS, Ryan JC, Van Dolah FM: Microarray validation: factors influencing correlation between oligonucleotide microarrays and realtime PCR. Biol Proced Online 2006, 8:175-193.

104. Ding Y, Xu L, Jovanovic BD, Helenowski IB, Kelly DL, Catalona WJ, Yang XJ, Pins $M$, Bergan RC: The methodology used to measure differential gene expression affects the outcome. J Biomol Tech 2007, 18(5):321-330.

Pre-publication history

The pre-publication history for this paper can be accessed here:http://www. biomedcentral.com/1471-2407/10/41/prepub

doi:10.1186/1471-2407-10-41

Cite this article as: Maślikowski et al:: Cellular processes of v-Src

transformation revealed by gene profiling of primary cells - Implications for human cancer. BMC Cancer 2010 10:41.

Submit your next manuscript to BioMed Central and take full advantage of:

- Convenient online submission

- Thorough peer review

- No space constraints or color figure charges

- Immediate publication on acceptance

- Inclusion in PubMed, CAS, Scopus and Google Scholar

- Research which is freely available for redistribution

Submit your manuscript at www.biomedcentral.com/submit
() Biomed Central 